\title{
Pelatihan dan Pendampingan Pendaftaran Merek Dagang bagi Pelaku Usaha Mikro Kecil Menengah (UMKM) di Banyumas
}

\author{
Wiga Maulana Baihaqi ${ }^{1 *}$, Christopher Prima ${ }^{2}$, Nabella Putri Widianto ${ }^{3}$ \\ 1,2,3Program Studi Teknologi Informasi, Fakultas Ilmu Komputer, Universitas Amikom Purwokerto \\ e-mail: wiga@amikompurwokerto.ac.id ${ }^{1}, \underline{w w w . c h r i s 0505 @ g m a i l . c o m ~}^{2}$, nabella048@gmail.com ${ }^{3}$ \\ * Penulis Korespondensi: E-mail: wiga@amikompurwokerto.ac.id
}

\begin{abstract}
Intellectual Property Rights (IPR) are legal guarantees against all forms of infringement of intellectual property rights that exist in Micro, Small and Medium Enterprises (MSMEs) entities. However, MSME actors still consider that IPR registration is a difficult job.. MSME actors need to receive socialization so that they can know the mechanism for using IPR registration applications, besides that they can find out information regarding the status of IPRs that have been submitted and received. Therefore, through this community service, the registration of intellectual property rights will be boldly disseminated and the purpose of this socialization is in Banyumas. The implementation of community service is carried out boldly by utilizing the Zoom application. There were two discussions delivered, namely the socialization of the importance of IPR owned by MSME actors and assistance in registering IPR, especially trademarks provided by the Directorate General of Intellectual Property. There were 37 registered participants, but only 25 participants took part in this activity. From the results of the questionnaire distributed to service participants, $72 \%$ of the participants strongly agree that this activity is very useful and absorbs new knowledge. 52\% of participants said they strongly agreed that they understood the material and $48 \%$ of participants agreed that they had understood the material. Finally, participants who want activities like this to be carried out again so that MSMEs increase their selling value.
\end{abstract}

Keywords: Banyumas, HKI, trademark, UMKM

\begin{abstract}
Abstrak
Hak Kekayaan Intelektual (HKI) adalah jaminan hukum terhadap segala bentuk pelanggaran hak kekayaan intelektual yang ada pada entitas Usaha Mikro, Kecil, dan Menengah (UMKM). Akan tetapi pelaku UMKM masih menganggap pendaftaran HKI adalah suatu pekerjaan yang sulit. Pelaku UMKM perlu mendapatkan sosialisasi agar mereka dapat mengetahui mekanisme penggunaan aplikasi pendaftaran $\mathrm{HKI}$, selain itu mereka dapat mengetahui informasi terkait status dari HKI yang sudah diajukan dan diterima. Oleh karena itu, melalui pengabdian kepada masyarakat ini, pendaftaran HKI secara daring akan disosialisasikan dan tujuan dari sosialisasi ini adalah memberikan pengetahuan kepada pelaku UMKM di Banyumas tentang pentingnya HKI bagi produk mereka dan meningkatkan keterampilan pelaku UMKM untuk menggunakan aplikasi dari Kementrian Hukum dan HAM untuk mendaftar HKI. Pelaksanaan pengabdian kepada masyarakat ini dilaksanakan secara daring dengan memanfaatkan aplikasi Zoom. Terdapat dua pembahasan yang disampaikan, yaitu sosialisasi pentingnya HKI dimiliki oleh pelaku UMKM dan pendampingan pendaftaran HKI khususnya merek dagang melalui aplikasi yang disediakan oleh Direktorat Jenderal Kekayaan Intelektual. Terdapat 37 peserta yang terdaftar, tetapi hanya 25 peserta yang mengikuti kegiatan ini. Dari hasil kuisioner yang dibagikan kepada peserta pengabdian, $72 \%$ dari peserta sangat setuju kegiatan ini sangat bermanfaat dan menyerap pengetahuan baru. Hingga $52 \%$ peserta mengatakan sangat setuju bahwa mereka memahami materi dan $48 \%$ peserta menyatakan setuju telah memahami materi. Terakhir adalah peserta menginginkan kegiatan seperti ini dillaksanakan Kembali agar UMKM semaHKIn meningkat nilai jualnya.
\end{abstract}

Kata Kunci: Banyumas, merek dagang, HKI, UMKM 


\section{PENDAHULUAN}

Keberadaan Usaha Mikro, Kecil dan Menengah (UMKM) dianggap penting dalam perekonomian Indonesia (Padyanawati \& Hardjomidjojo, 2019). UU Nomor 20 Tahun 2008 tentang UMKM merupakan payung hukum yang mengatur pelaksanaan UMKM. Dalam UU tersebut menjelaskan pengertian dari usaha mikro, usaha kecil dan usaha menengah serta tentang kepemilikan usaha tersebut. Kabupaten Banyumas menjadi salah satu kabupaten yang fokus pada pengembangan UMKM. Sampai saat ini tercatat di Dinas Tenaga Kerja, Koperasi dan UKM Kabupaten Banyumas bahwa jumlah UMKM sebanyak 84.350 yang terbagi menjadi Sembilan sektor.

Salah satu sektor yang tahan banting dari kendala perekenomian di Indonesia adalah sektor UMKM (Lumintang et al., 2019). Terbukti sekarang walaupun pandemic COVID-19 sedang menyerang Indonesia, tetapi UMKM mampu mempertahankan keberlanjutan bisnisnya. Akan tetapi pandemi COVID-19 ini juga membuat UMKM yang kesulitan dalam menjalankan bisnisnya seperti yang dialami oleh pelaku UMKM di Kabupaten Banyumas, mereka masih berusaha agar tetap dapat menjalankan bisnisnya di tengah pandemic COVID-19.

Pemerintah Kabupaten Banyumas bergerak cepat untuk merespon kesulitan UMKM yang disebabkan oleh pandemi COVID-19. Terdapat inovasi yang dihasilkan oleh pemerintah dengan nama Gerakan Legalisasi Usaha Mikro Kecil Menengah Banyumas, inovasi tersebut memiliHKI singkatan Gelas Umi Kece Mas. Legalisasi UMKM adalah tujuan utama dari peluncuran inovasi dari Pemerintah Kabupaten Banyumas, diharapkan UMKM di Kabupaten Banyumas memiliHKI legalisasi usaha khususnya pada merek dagang yang dapat diajukan ke Kementerian HUKUM dan HAM yang berada pada bagian MPP Kabupaten Banyumas.

Dalam upaya perlindungan Kekayaan Intelektual perlu adanya pendaftaran Kekayaan Intelektual agar mempunyai perlindungan hukum terhadap Kekayaan Intelektual yang sudah diciptakan melalui hasil kreatifitas intelektualnya (Yanto, 2015). Pelaku UMKM apabila ingin mendapatkan Kekayaan Intelektual, maka harus melakukan pendaftaran. Beberapa cabang Kekayaan Intelektual yang diwajibkan dilakukanya pendaftaran agar mendapatkan perlindungan dan kepastian hukum yang jelas yaitu Merek, Paten, Desain, Industri, Desain Tata Letak Sirkuit Terpadu, Rahasia Dagang, dan Perlindungan Varietas Tanaman. Prinsip ini mendasari hukum kekayaan intelektual di seluruh dunia dan mengaHKIbatkan ketidakmampuan pemilik kekayaan intelektual yang tidak terdaftar untuk menuntut siapa pun yang dicurigai telah menggunakan kekayaan intelektual mereka secara illegal (Budi Asri, 2020).

Pentingnya pendaftaran Kekayaan Intelektual khususnya di beberapa bidang Kekayaan Intelektual yang mewajibkan melakukan pendaftaran untuk mendapat perlindungan hukum bagi penciptanya (Journal et al., 2016). Berkembangnya sistem teknologi sekarang ini membuat berbagai sektor banyak menggunakan sistem online. Selain lebih mudah dan tidak membutuhkan waktu yang lama, sistem online dirasa efektif dan efisien karena dapat dilakukan dimana saja dan kapan saja. Dirjen Kekayaan Intelektual Kementerian Hukum dan HAM RI juga memanfaatkan kemajuan teknologi dalam sistem pendaftaran Kekayaan Intelektual dengan cara online. Sistem ini kerjasama antara Dirjen Kekayaan Intelektual Kementerian Hukum dan HAM RI dengan badan internasional yang khusus mengelola dan mengadministrasikan kesepakatan bersama antara negara di bidang Kekayaan Intelektual yaitu WIPO (World Intellectual Property Organization).Perlunya pemahaman masyarakat terkait layanan online Kekayaan Intelektual khususnya bagi UMKM agar mempunyai kemauan untuk mendaftarkan produk yang dihasilkan tanpa mempunyai anggapan mendaftar HKI butuh waktu yang lama dan prosedur yang terlalu sulit sehingga produk pelaku UMKM akan mendapatkan perlindungan hukum yang jelas, 
untuk itu perlu diadakannya sosialisasi kepada masyarakat khususnya UMKM yang mempunyai Kekayaan Intelektual agar mau untuk mengajukan permohonan pendaftaran HKI. Pendaftaran Kekayaan Intelektual sekarang ini dapat dilakukan secara online dengan membuka aplikasi yang sudah ada dalam web Dirjen HKI Kementerian Hukum dan HAM RI.

Kurangnya pemahaman dan kesadaran masyarakat khususnya para pelaku UMKM di Kabupaten Banyumas, diperlukannya upaya penyadaran pentingnya pendaftaran Kekayaan Intelektual agar mau mendaftarkan Kekayaan Intelektual yang dimiliki agar mendapat perlindungan hukum yang jelas (Ferliadi, 2020). Kesadaran dan pemahaman tentang pendaftaran HKI secara online bagi masyarakat luas pada umumnya dan pelaku UMKM pada khususnya masih sangat kurang, karena pada dasarnya pemikiran kebanyakan orang bahwa mendaftarkan HKI membutuhkan waktu yang sangat lama dan persyaratan yang rumit. Tidak terkecuali di Kabupaten Banyumas yang terdiri dari sentra industri UMKM yang menjadi unggulan Kabupaten Banyumas. Akan tetapi terkait sistem layanan Kekayaan Intelektual online belum disosialisasikan oleh instansi terkait kepada masyarakat luas.

\section{METODE PELAKSANAAN}

Pada pelaksanaan pengabdian kepada masyarakat ini terdiri dari empat tahapan, seperti yang ditunjukkan pada Gambar di bawah ini.

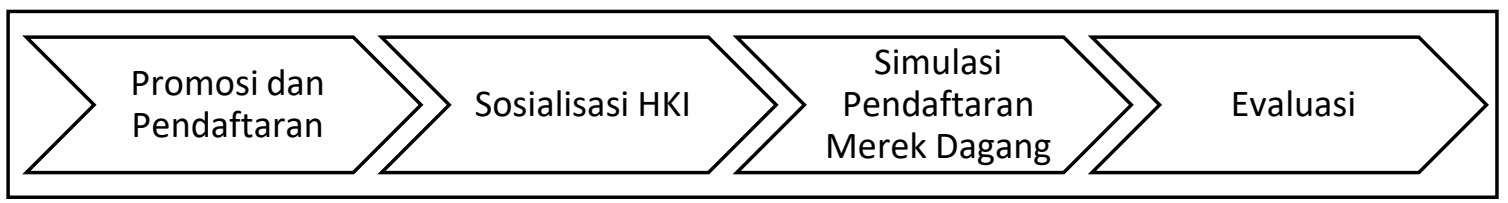

Gambar 1. Tahapan Pelaksanaan Pengabdian kepada masyarakat

\section{Promosi dan Pendaftaran}

Target sasaran peserta dari kegiatan Pengabdian kepada Masyarakat ini adalah pelaku Usaha Mikro Kecil dan Menengah (UMKM) yang ada di Kabupaten Banyumas, akan tetapi tidak membatasi pelaku UMKM di luar daerah Banyumas untuk tetap dapat mendaftar dan mengikuti kegiatan. Promosi dilakukan dengan memanfaatkan sosial media Instagram, tim pengabdian meminta bantuan kepada startup di bidang Pendidikan yang bernama damar.in untuk membantu promosi kegiatan di akun Instagram-nya dan menyediakan media untuk melakukan pendaftaran bagi UMKM yang akan mendaftar. Media pendaftaran dilakukan dengan memanfaatkan website yang dimilki oleh startup damar.in. 2. Sosialisasi HKI

Setalah tahap promosi dan pendaftaran selesai, maka dilanjutkan kegiatan Pengabdian kepada Masyarkat hari pertama yaitu dengan menyampaikan materi pentingnya HKI bagi pelaku UMKM. Kegiatan sosialisasi atau penyampaian materi dilakukan dengan memanfaatkan aplikasi Zoom untuk menjaga penyebaran virus COVID19.

\section{Simulasi Pendaftaran Merek Dagang}

Setalah peserta mendapatkan materi pentingnya HKI bagi pelaku UMKM, dihari berikutnya dilanjutkan dengan kegiatan simulasi pendaftaran merek dagang melalui laman https://dgip.go.id/. Peserta diharapkan pada kegiatan ini dapat mengikuti langkah demi Langkah dalam pendaftaran merek dagang.

4. Evaluasi

Evaluasi kegiatan dilakukan dengan cara memberikan kuesioner kepada peserta webinar setelah pemaparan materi webinar selesai. Kuesioner dibuat dengan 
memanfaatkan Google Form. Penilaian tersebut dengan menggunakan skala likert rentang $1-5$.

\section{HASIL dan PEMBAHASAN}

Tim pengabdian memanfaatkan Sosial Media Instagram untuk menyebarkan Informasi mengenai kegiatan ini, Tim meminta bantuan kepada startup damar.in untuk menjadi pengelola kegiatan ini. Tim damar.in bertugas mulai dari pencarian peserta kegiatan, pelaksanaan, dan paska kegiatan. Pertama dalam pencarian peserta, tim damar.in menyediakan poster kegiatan agar dapat di unggah di media sosial, kemudian dalam proses pendaftaran juga disediakan platform website dari damar.in sehingga peserta UMKM yang tertarik untuk mengikuti kegiatan ini dapat mengunjungi website dan mengisi data pada formulir yang sudah disediakan oleh tim startup damar.in. Dalam proses pelaksanaan, tim damar.in menyediakan fasilitas berupa tempat untuk menyampaikan materi kegiatan beserta dengan internet, dan juga ada fasilitas aplikasi Zoom dengan status aplikasi berlisensi. Terakhir pada akhir kegiatan, tim damar.in akan memfasilitasi untuk editing video kegiatan yang dapat digunakan untuk publikasi kegiatan di social media seperti Instagram dan Youtube.

Berikut merupakan Gambar poster yang berada pada akun Instagram @damar_in, pelaku UMKM yang ada di Banyumas atau di luar Banyumas dapat mendaftar melalui tautan yang disediakan di Poster. Dari hasil promosi kegiatan melalui poster yang diunggah di akun Instagram @damar_in menghasilkan peserta sebanyak 37 Peserta. Tim damar.in memanfaatkan layanan iklan yang disediakan oleh Instagram agar dapat menjangkau para pelaku UMKM yang membutuhkan materi dan pelatihan tentang HKI.
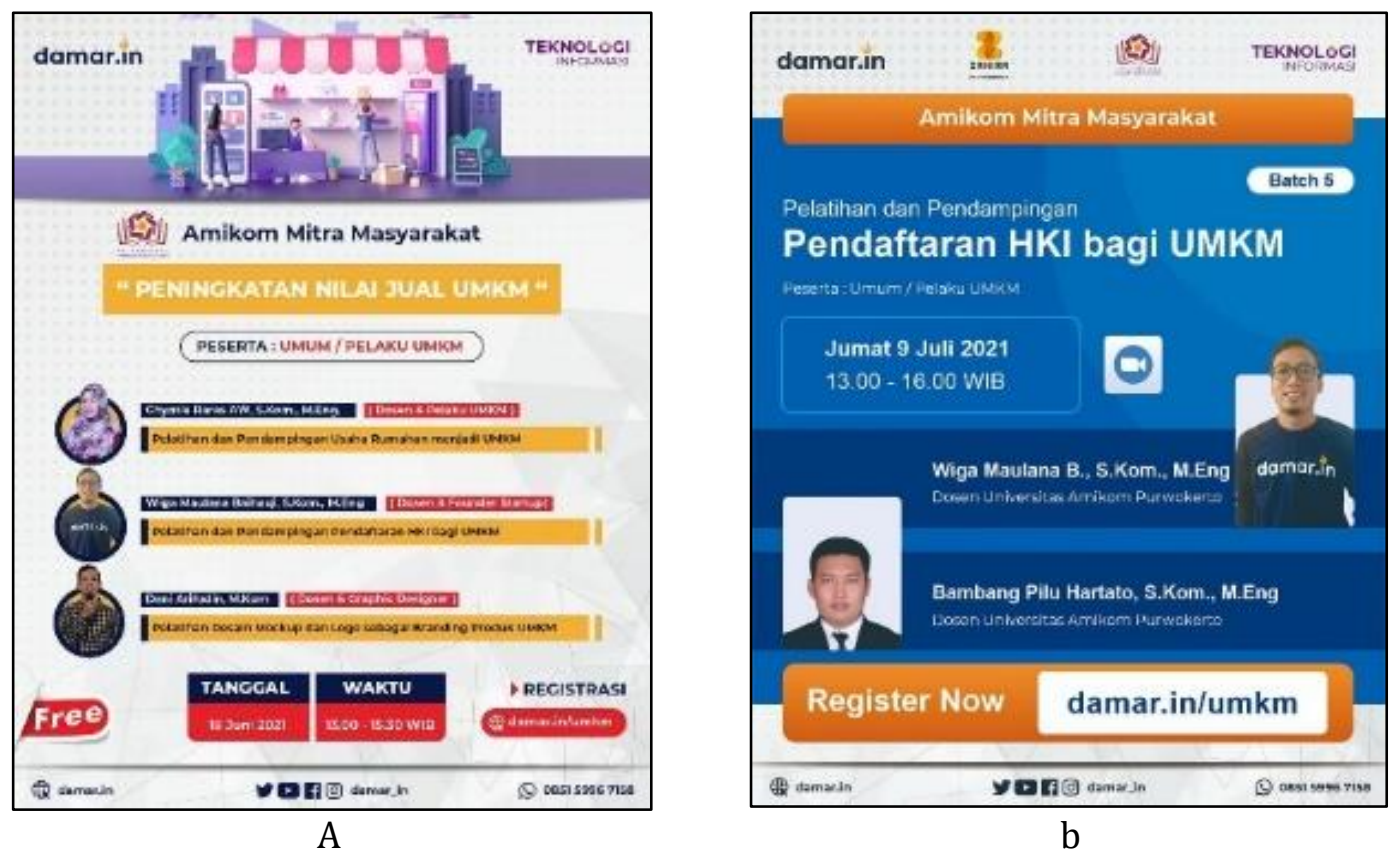

Gambar 2. Poster Kegiatan (a) Hari Pertama (b) Hari Kedua (Sumber: Instagram @damar_in)

Pada saat pelaksanaan kegiatan dihari pertama dan kedua, tidak semua peserta yang mendaftar mengikuti kegiatan. Jumlah peserta yang mengikuti kegiatan hanya 25 peserta. Gambar 2 menunjukkan kegiatan sosialisasi tentang pentingnya Hak Kekayaan 
Intelektual bagi pelaku UMKM, tidak hanya itu materi yang disampaikan juga menambahkan pengetahuan tentang Hak Kekayaan Intelektual dan Jenis-jenis Hak Kekayaan Intelektual.

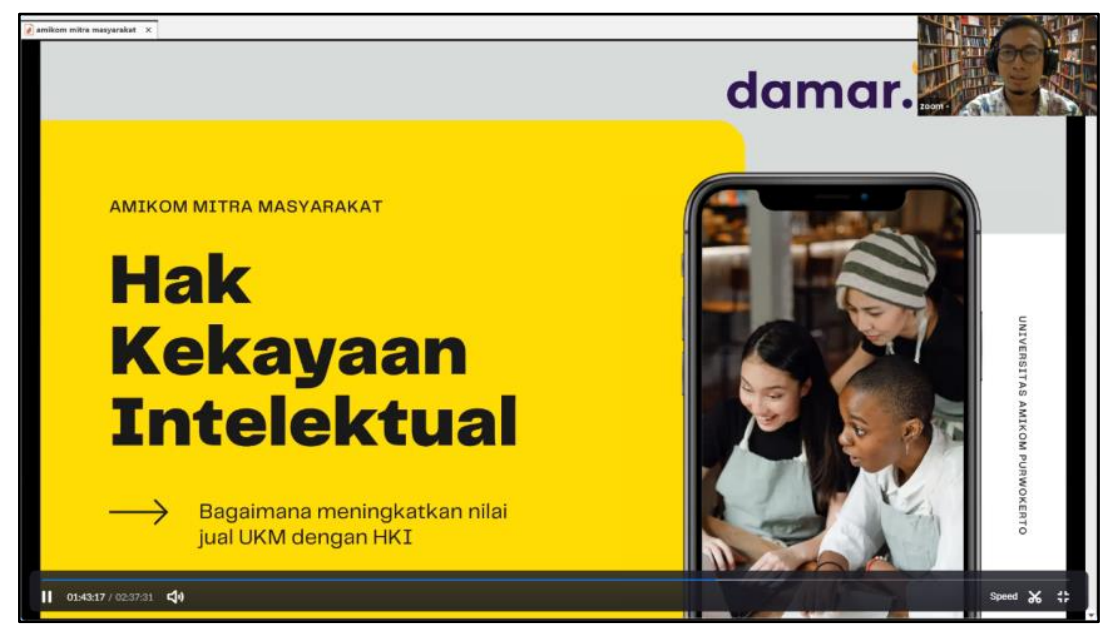

Gambar 3. Sosialisasi tentang Hak Kekayaan Intelektual (HKI)

Gambar 3 menunjukkan kegiatan pelatihan mekanisme pendaftaran HKI bagi pelaku UMKM melalui laman https://dgip.go.id/_,pemateri pada sesi ini tidak hanya menyampaikan materi , tetapi mengajak peserta kegiatan untuk ikut membuka website dari Direktorat Jendral Kekayaan Intelektual Kementrian Hukum dan HAM Republik Indonesia. Hal tersebut dilakukan agar peserta dapat memahami fitur-fitur yang ada pada website tersebut dan mengetahui langkah dari awal hingga akhir pendaftaran. Dari hasil kegiatan pada sesi ini ada beberapa UMKM yang mempraktekan untuk pendaftaran merek dagang pada usaha sendiri, akan tetapi karena banyak berkas atau dokumen pendukung yang belum disiapkan oleh peserta, merekapun menggunakan dokumen yang seadanya. Kemudian mereka terhenti pada tahap pembayaran, karena memang masih perlu adanya pertimbangan yang matang untuk mendaftarkan merek dagang dari UMKM.

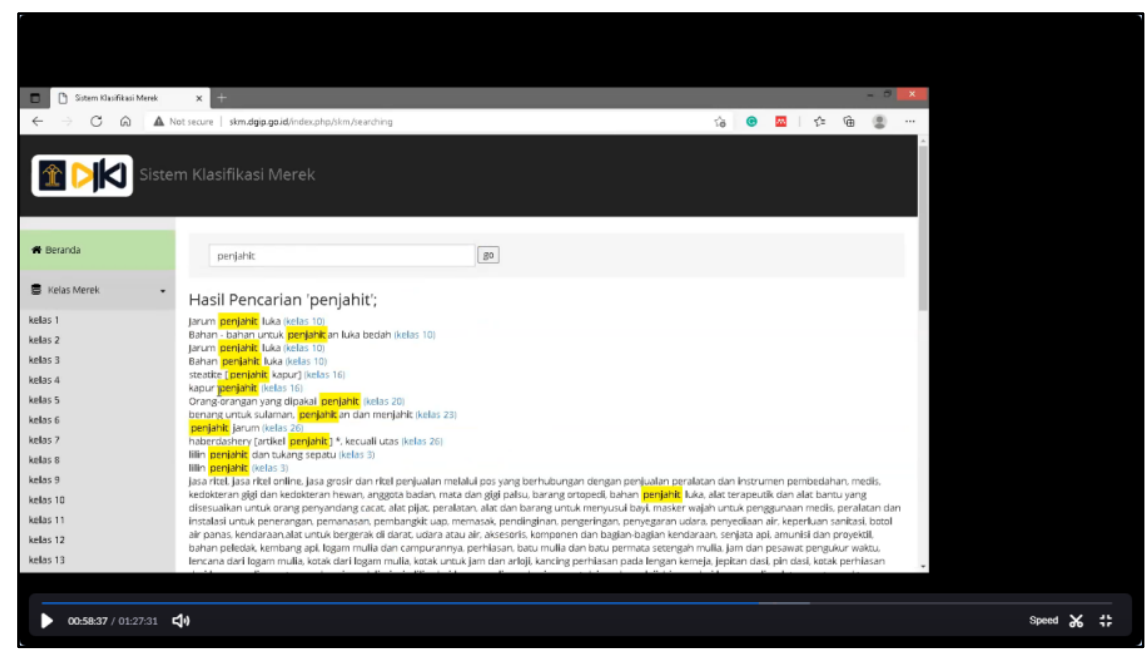

Gambar 4. Pelatihan Pendaftaran Merek Dagang

Setelah memberikan materi dan workshop, para peserta diminta untuk mengisi kuesioner. Survei ini bertujuan untuk mengetahui lebih lanjut minat peserta dalam kegiatan 
pengabdian masyarakat melalui webinar. Gambar 4 menunjukkan hasil kuesioner dari peserta mengenai kemanfaatan materi.

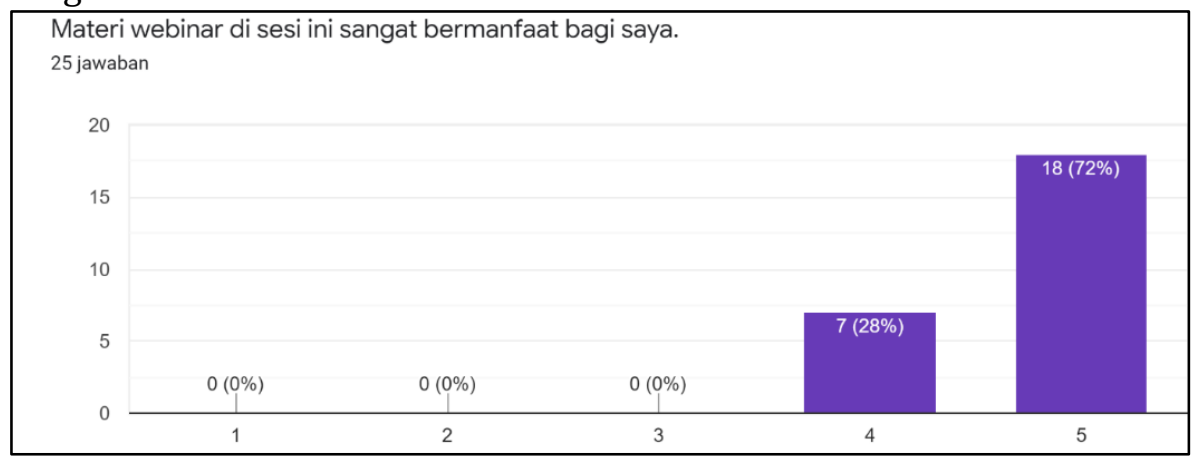

Gambar 4. Hasil Kuesioner Peserta Mengenai Kemanfaatan Materi

(Sumber: Hasil Kuisioner)

Berdasarkan Gambar 4, 18 dari 25 peserta atau 72\% menyatakan sangat setuju bahwa mereka menilai kegiatan pengabdian kepada masyarakat yang diadakan secara daring, sisanya sebanya 7 peserta atau $28 \%$ menilai setuju kegiatan bermanfaat bagi peserta.

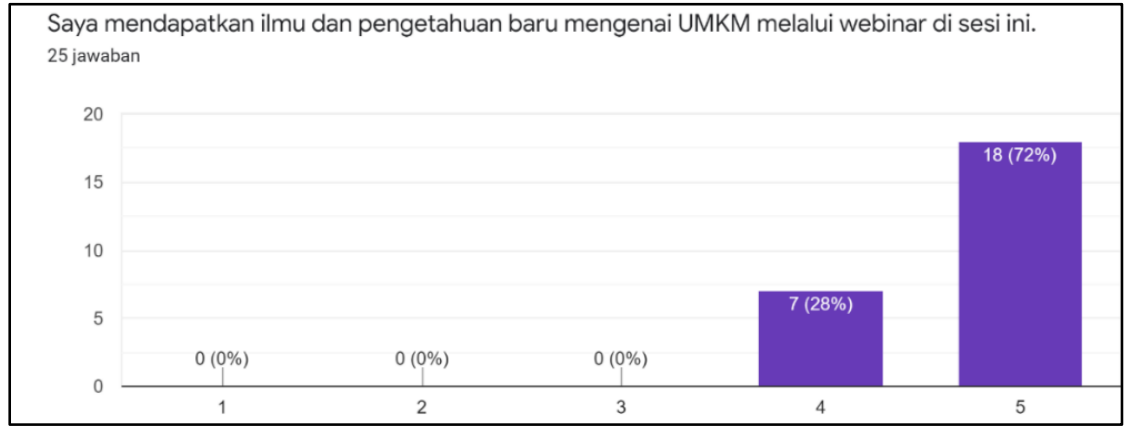

Gambar 5. Hasil Kuesioner Peserta Mengenai Kemanfaatan Materi (Sumber: Hasil Kuisioner)

Berdasarkan Gambar 5, 18 dari 25 peserta atau 72\% menyatakan bahwa mereka sangat setuju mendapatkan ilmu dan pengetahuan baru mengenai HKI dan UMKM, sisanya sebanya 7 peserta atau $28 \%$ menilai setuju kegiatan tersebut dapat menambahkan ilmu dan pengetahuan baru mengenai UMKM dan HKI.

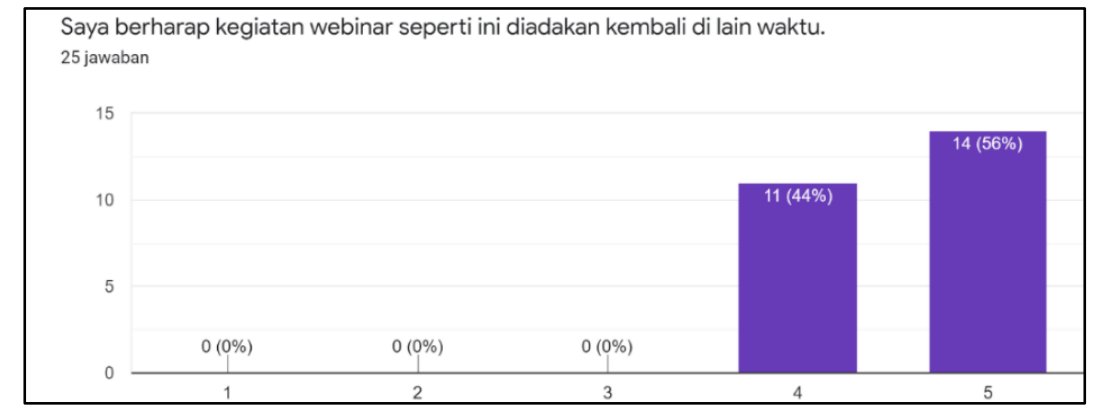

Gambar 6. Hasil Kuesioner Peserta Mengenai Keberalnjutan Kegiatan (Sumber: Hasil Kuisioner) 
Berdasarkan Gambar 6, 14 dari 25 peserta atau 56\% menyatakan bahwa mereka sangat setuju kegiatan pengabdian dengan tema UMKM diadakan lagi di lain waktu, sisanya sebanyak 11 peserta atau $44 \%$ menilai setuju kegiatan pengabdian dengan tema UMKM diadakan lagi di lain waktu.

\section{KESIMPULAN}

Kegiatan pengabdian kepada masyarakat yang dilaksanakan secara daring berhasil dilaksanakan. Melalui kegiatan pengabdian kepada masyarakat ini, pelaku UMKM mayoritas menilai sangat setuju bahwa kegiatan pengabdian kepada masyarakat ini sangat bermanfaat, mendapatkan ilmu pengetahuan baru tentang UMKM dan HKI, dan perlu diadakan lagi kegiatan di lain waktu. Peserta mengaku tertarik untuk mulai menyiapkan persyaratan untuk mendaftarkan merek dagang mereka agar mendapatkan perilindungan hukum. Dibalik keberhasilan kegiatan ini, ada juga kendala yang dihadapi yaitu terkait koneksi internet yang digunakan untuk menyelenggarakan kegiatan, beberapa kali terjadi putus jaringan saat kegiatan berlangsung. Kedepannya dalam mengadakan kegiatan pengabdian kepada masyarakat secara daring, perlu persiapan yang matang terkait koneksi internet.

\section{UCAPAN TERIMAKASIH}

Kegiatan Pengabdian kepada Masyarkat ini atau disebut Amikom Mitra Masyarakat ini dapat berjalan dengan baik karena ada bantuan dana dari Lembaga Penelitian dan Pengabdian kepada Masyarakat dan damar.in sebagai media partner untuk menyelenggarakan kegiatan ini, sehingga kami ucapkan terimakasih kepada kedua Lembaga tersebut.

\section{DAFTAR PUSTAKA}

Budi Asri, D. P. (2020). Perlindungan Hukum Hak Kekayaan Intelektual Bagi Produk Kreatif Usaha Kecil Menengah Di Yogyakarta. Jurnal Hukum Ius Quia Iustum, 27(1), 130-150. https://doi.org/10.20885/iustum.vol27.iss1.art7

Ferliadi, A. S. (2020). Implementasi Hak Kekayaan Intelektual Pada Bidang Usaha Mikro Kecil Dan Menengah (Study Kasus Di Kota Metro). Humani (Hukum Dan Masyarakat Madani), 10(1), 44-61. https://core.ac.uk/download/pdf/327164153.pdf

Journal, D. L. A. W., Asean, M. E., \& Journal, D. L. A. W. (2016). Perlindungan Produksi Usaha Mikro Kecil dan Menengah Terkait Hak Kekayaan Intelektual dalam Menghadapi Masyarakat Ekonomi ASEAN. Diponegoro Law Journal, 5(3), 1-11.

Lumintang, J. J., Rumate, V. A., \& Rotinsulu, D. C. (2019). Analisis Dampak Kebijakan Penyaluran Kredit Kepada Umkm Terhadap Pertumbuhan Kredit Di Provinsi Sulawesi Utara. Jurnal Pembangunan Ekonomi Dan Keuangan Daerah, 20(2), 1. https://doi.org/10.35794/jpekd.24051.20.2.2019

Padyanawati, A. D., \& Hardjomidjojo, H. (2019). Strategi Peningkatan Daya Saing Usaha Mikro, Kecil, Dan Menengah Di Desa Tegalwaru, Kabupaten Bogor. Jurnal Rekayasa $\begin{array}{llll}\text { Dan } & \text { Manajemen } & \text { Agroindustri, } & 7(1),\end{array}$ https://doi.org/10.24843/jrma.2019.v07.i01.p15

Yanto, O. (2015). KONSEP PERLINDUNGAN HAK CIPTA DALAM RANAH HUKUM HAK KEKAYAAN INTELEKTUAL (Studi Kritis Pembajakan Karya Cipta Musik dalam Bentuk VCD dan DVD). Yustisia Jurnal Hukum, 93(3), 746-760. https://doi.org/10.20961/yustisia.v93i0.3702 